Başvuru : 24.04.2016

Kabul : : 10.01.2017

\title{
İşten Ayrılma Niyeti ile Örgütsel Sessizlik Etkileşiminde İ̧̧ Güvencesi Memnuniyeti ve İş Güvencesi Endeksinin Aracı Rolü: Özel Bir Hastane Çalışanları Üzerinde Bir Araştırma ${ }^{1}$
}

Serdar Uslu ${ }^{2}$

Hakkı Aktaş ${ }^{3}$

İşten Ayrılma Niyeti ile Örgütsel Sessizlik Etkileşiminde İş Güvencesi Memnuniyeti ve İş Güvencesi Endeksinin Aracı Rolü: Özel Bir Hastane Çalışanları Üzerinde Bir Araştırma

Öz

$\mathrm{Bu}$ araştırmanın amacı, bireylerin işten ayrılma niyetleri ile örgütsel sessizlik etkileşiminde iş güvencesi memnuniyeti ve iş güvencesi endeksinin aracılık etkisinin belirlenmesidir. Araştırma İstanbul merkezli bir özel hastaneler zincirinde çalışan sağlık hizmetleri çalışanlarının katılımıyla gerçekleştirilmiştir. Araştırmada Dyne vd. (2003) tarafından geliştirilen örgütsel sessizlik ölçeği ile Wayne vd. (1997) tarafından geliştirilen işten ayrılma niyeti ölçeği ve Probst (1998) tarafından geliştirilen iş güvencesi memnuniyeti ve iş güvencesi endeksi ölçekleri kullanılmıştır Elde edilen bulgulara göre örgütsel sessizlik ile işten ayrılma niyeti etkileşiminde iş güvencesi memnuniyetinin kısmî aracılık etkisi tespit edilmiştir. Örgütsel sessizlik, işten ayrılma niyeti ve iş güvencesi memnuniyeti demografik faktörler bağlamında istatistikî olarak anlamlı farklılıklar göstermektedir.

Anahtar Kelimeler: Örgütsel Sessizlik, İşten Ayrılma Niyeti, İ̧̧ Güvencesi Memnuniyeti, İş Güvencesi Endeksi.
The Mediating Roles of Job Security Satisfaction and Job Security Index in The Interaction Between Organizational Silence and Intentions to Quit: A Research on A Private Hospital Staff

Abstract

The purpose of this research is to determine the mediating effect of job security satisfaction and job security index in interaction between organizational silence and intentions to quit of individuals. Research conducted on the employees of health services in a private hospital chain in Istanbul. In research organizational silence scale was developed by Dyne etc. (2003), for measuring the intentions to quit scale was developed by Wayne etc. (1997) and job security satisfaction and job security index scale was developed by Probst (1998) were used. According to the findings, there is a partial mediating effect of job security satisfaction in the interaction between organizational silence and intentions to quit. There are statistically meaningful differences of organizational silence, intentions to quit and job security satisfaction among demographic factors.

Keywords: Organizational Silence, Intentions to Quit, Job Security Satisfaction, Job Security Index.

\section{Giriş}

Toplumda nüfusun yaşlanmasıyla birlikte sağlık hizmetlerine olan talebin artması, sağlık sektöründe faaliyet gösteren işletmeler açısından nitelikli işgücü ihtiyacını ön plana çıkarmıştır. Bununla birlikte mevcut işgörenlerin elde tutulması, işten ayrılmaların örgütte yaratacağı kurumsal hafıza kaybı ve iş gücü devri de önem kazanmıştır. Waldman vd. (2004: 3-5) işten ayrılma kaynaklı kayıp maliyetin işletmelerin yıllık bütçesinin ortalama \% 5'ini oluşturduğunu belirtmektedir. Tourangeau ve Cranley (2006: 8-9) ise Kanada'da hemşireler üzerinde gerçekleştirdikleri araştırmalarında iş tatminsizliği faktörünün işten ayrılmalarda en önemli etken olduğunu tespit etmiştir.

\footnotetext{
${ }^{1}$ Bu çalışma Bahçeşehir Üniversitesi SBE'nde Doç. Dr. Hakkı Aktaş danışmanlığında Serdar Uslu tarafından yapılan "Örgütsel Sessizlik ile İşten Ayrılma Niyeti ve İş Güvencesi Memnuniyeti Etkileşimi: Özel Hastane Çalışanları Üzerinde Bir Araştırma" isimli yüksek lisans tezinin geliştirilmiş versiyonudur.

${ }^{2}$ Bahçeşehir Üniversitesi. serdaruslu79@hotmail.com

${ }^{3}$ Doç. Dr., İstanbul Üniversitesi. hakki.aktas@istanbul.edu.tr
} 
Pek çok araştırmacı tarafından bireysel açıdan incelenen işgören sessizliği, Morrison ve Milliken (2000)'i doğrular nitelikte Brinsfield vd. (2009) tarafından da bireysel düzeyden başlayarak örgütteki diğer işgörenleri de etkileyebileceğini değerlendirilmiş ve sesin çerçevesi, fikir düşünce ve endişenin ifadesi olarak çizilmiştir. Luchak'ın (2003) örgütsel bağlılık ekseninde yaptığı çalışmada işten ayrılma düşüncesi ile "sessiz kalmamak" olgusu incelenmiş, Kolarska ve Aldrich (1980: 44) ise konuyu işte kalarak sessizleşme ve işten ayrılma şekliyle ele almıştır. Diğer taraftan Hoffmann'ın (2006: 2313) bireylerin iş tatminsizliği ve haksızlık karşısındaki tutumunu, örgütte kalarak sesini çıkartma ya da işten ayrılma ikileminde ele alması (Çakıcı, 2007: 151), Bagheri vd. (2012: 56) ise örgütsel sessizliğin işten ayrılmaları ve iş doyumunu etkilediğini belirtmesi, örgütsel sessizlik ile işten ayrılma niyeti arasında güçlü bir neden-sonuç ilişkisi içinde olabileceğini düşündürmektedir. Bu nedenle, her iki değişkenin birbiri ile olan ilişkisinde dikkate alınması gereken üçüncü bir değişkenin aracı etkisinin incelenmesinin örgütler açısından faydalı olacağı değerlendirilmiştir.

Bu açıdan bakıldığında, stratejik insan kaynakları yönetiminde önemli yere sahip evrenselci kuram yaklaşımında (Becker ve Gerhart, 1996; Delery ve Doty, 1996; Huselid, 1995; Osterman, 1994; Pfeffer, 1994) işletmelerin verimlilik ve kârlılıklarının artırılmasına yönelik en iyi insan kaynakları uygulamaları arasında bulunan iş güvencesinin (Akt.: Gürbüz, 2013: 10) aracı değiş̧ken olarak, işgörenlerin iş güvencesi memnuniyetleri ile iş güvencesinin geleceğe dair algılarından oluşturan Probst (1998)'a ait iş güvencesi endeksi araştırmaya dâhil edilmiştir.

\section{Kavramsal Çerçeve}

\section{1. Örgütsel Sessizlik}

Sessizlik, TDK tarafından "konuşmama, söz söylememe" anlamı taşıyan sükût kelimesiyle eş anlamlı kullanılmıştır (Uslu ve Aktaş, 2015: 78). Sessizlik ve ses ile ilişkilendirilen kavramlar, araştırmacılar tarafından üzerinde 50 yılı aşkın bir süredir ilgilenilen bir konudur (Zehir ve Erdoğan, 2011: 1390). Sessizlik davranışının bireysel ve örgütsel bağlamda olumsuz yansımaları bulunmakta (Bagheri vd., 2012: 50) diğer bir ifadeyle, sessizlik örgütteki olumsuz deneyimlerin sonucu edinilen tutumlar olarak karşımıza çıkmaktadır (Uslu ve Aktaş, 2015: 78). Hirscman (1970) sesi örgütsel açıdan ele almış, çalışanların çıkış ve ses kavramlarıyla örgütlerine karşı tepki gösterdiğini belirtmiştir. Çıkış, çalışanın örgütle ilişkisini bitirmesi, ses ise itiraz etme ve tavsiyede bulunma olarak tanımlanmaktadır (Tangirala vd. 2008: 40, Hirschman 1970: 4). Morrison ve Milliken (2000) ise sessizliği örgütsel anlamda işgörenlerin iradeleriyle istemli ve kasıtlı bir şekilde susması olarak açıklamıştır. Örgütsel sessizlik, örgütsel iletişim bağlamında yaşam doyumu ile anlamlı bir ilişki içerisinde bulunmakta ve örgütsel iletişim pratikleri bireylerin tüm sosyal yaşamını etkilemektedir (Şimşek ve Aktaş, 2015: 148). Çakıcı'ya (2010: 37) göre anlaşılması ve yorumlanması zor bir davranış olan sessizlik, işgörenin örgütsel performansı üzerinde belirleyici bir unsurdur. Yapılan çalışmalarda sessizlik ve ses kavramlarının işten ayrılma ile güçlü ilişki içinde olduğu tespit edilmiştir (Avery ve Quinones, 2004: 181; Keeley ve Graham, 1991: 350).

Örgütsel sessizlik nedenleri bağlamında örgütsel adalet, örgüt iklimi, sinizm, iş güvencesizliği, örgüt kültürü, liderlik türleri gibi birçok kavram ile birlikte araştırmalarda irdelenen konu olmuştur (Çakıcı, 2010; Çakıcı, 2007; Milliken vd., 2003; Premeaux ve Bedeian, 2003; Bowen ve Blackmon 2003; Pinder ve Harlos, 2001). Örgütsel sessizlik çeşitli araştırmalarda farklı boyutlarla sınıflandırılmıştır. Sessizliği pasif bir tutum olarak ele alan çalışmalar (Scott, 1993) bulunmasına rağmen, Brinsfield (2009) bireysel, çevresel ve örgütü korumaya yönelik sessizlik tutumlarının varlığından da söz etmiştir. Pinder ve Harlos (2001) tarafından ise kabullenici 
sessizlik ve savunmacı sessizlik olarak iki boyuta ayrılan bu sınıflamaya ilişkisel sessizlik boyutu Dyne vd., (2003) tarafından eklenmiştir (Karacaoğlu ve Cingöz, 2009: 701).

Aktaş ve Şimşek (2014: 25)'e göre sessizlik sağlık sektörü için çok önemli bir konu olup sessizlik ikliminde, yaşamı etkileyen kritik hataların işgörenler tarafından söylenmemesi ve örgüte yönelik iyileştirici yönde katkıların yapılmaması anlamına gelmektedir. Sağlık sektörü çalışanlarının örgütsel sessizlik tutumunu sergilemesinin sonuçları Henriksen ve Dayton (2006: 1541) tarafından da ifade edildiği üzere hasta sağlığı açısından fark edilemez bir tehlikedir.

\subsubsection{Kabullenici Sessizlik}

Dyne vd., (2003: 1363)'nin tanımlamasına göre kabullenici sessizlik işgörenlerin mevcut durumdan rahatsızlık duymalarına rağmen iyileştirici yöndeki öneri, çalışma ve fikirlerini istemli şekilde esirgemeleridir. Bireylerin sahip olduğu başkalarına saygı, ihtiyatlılık, nezaket gibi değerler (Beheshtifar vd., 2012: 276), çatışma ve utanç gibi tehlike algılarını önlemek için (Perlow ve Williams, 2003: 3) "geçinmek için susma" tutumunu meydana getirebilmekte, çevresel aktörlere karşı tepkisizlik ve konuşma eylemlerinde isteksizlik yaratabilmektedir.

\subsubsection{Savunmacı Sessizlik}

Savunmacı sessizlik ise durumun kötüye doğru gitme ihtimaline karşı duyulan umutsuzluk ve çaresizlik algısıdır (Brinsfield, 2009: 21). Savunmacı sessizlik, kabullenici sessizlik gibi olumsuz algı yaratmakta ancak bu durumun kabul edilebilir düzeyde olduğunu ortaya koymaktadır. Dışadönüklük ve yaşamsal tatmin düzeyi düştükçe kabullenici ve savunmacı sessizlik eğilimi artarken diğer taraftan yenilikçi ve dışadönük kişilik özelliği yüksek olan ve kendi özyeterliliğine güvenen işgörenler, kabullenici ve savunmacı sessizlik davranışı göstermemekte ancak ilişkisel sessizlik davranışlarında bulunabilmektedirler (Şimşek ve Aktaş, 2014: 131-132). Savunmacı sessizlik, bireyin örgütsel bağlılığını olumsuz yönde etkilemektedir (Deniz, Noyan ve Ertosun, 2013: 698).

\subsubsection{Iliş̧kisel Sessizlik}

Dyne vd. (2003: 1360-1361) tarafından Pinder ve Harlos (2001)'un sessizlik tanımlaması genişletilerek kabullenici ve savunmacı sessizlik boyutlarına, örgütün veya kişilerin yararına işle ilgili fikirlerin gizlenmesi olarak nitelendirilen "toplumcu sessizlik" kavramını eklenmiştir. iliş̧kisel sessizlik olarak da adlandırılan bu sessizlik türünde işgörenler, diğer iki sessizlik türünden farklı olarak bireyselliklerinin dışında başkaları için duydukları korku ve endişeden kaynaklanan koruyucu davranış tutumu sergilemektedirler. İlişkisel sessizlik, kabullenici ve savunmacı sessizliğe göre daha yapıcı etkenler içermektedir. Örgüt ile çalışan ilişkilerin korunmasına yönelik sergilenen bu sessizlik tutumu iş tatminsizliği, tükenmişlik hissi, duyarsızlaşma ile atalet hissi yaratmamakta ancak bireysel performansı olumsuz yönde etkilediğinde iş doyumunu azalabilmektedir (Aktaş ve Şimşek, 2015: 218-219).

\section{3. İşten Ayrılma Niyeti}

İşten ayrılma niyeti, bireylerin mevcut işlerini veya mesleklerini bırakarak, yeni bir iş ya da meslek arama isteğini ifade etmektedir (Çekmecelioğlu 2014: 26). İ̧̧ten ayrılma niyeti, işgörenlerin yapmakta oldukları işten memnuniyetsizlik duymaları halinde sergiledikleri yıkıcı ve aktif eylem olarak tanımlanabilir (İşçi, 2010: 67). İşten ayrılma niyeti alanyazında, işgörenin bağlı olduğu örgütünden ayrılmayı bilinçli bir şekilde planlayarak gerçekleştirme isteği ve bu isteğin sürekliliği olarak ifade edilmektedir (Büyükyılmaz ve Çakmak, 2014: 585; Cho vd., 2009:374; Tett ve Meyer, 1993: 262; Rusbult vd., 1988: 601). Bu eylemi işgörenin örgütten ayrılmak için kasıtlı yaptığı bir eylem olarak gören kaynaklar da mevcut olup (Egan vd., 2004: 
279; Meyer vd., 2002: 92) işten ayrılma niyetini alternatif iş imkânları arama sürecin bir parçası olarak görülmektedir (Meyer vd., 2002: 92).

Işsten ayrılma sürecinden önceki en önemli aşama olan işten ayrılma niyeti, işgören tarafından birçok girdinin bir arada değerlendirildiği, karmaşık ve psikolojik açıdan işgöreni etkisi altına alabilecek bir süreçtir. Araştırmalar, iş doyumu düşük olan kişilerin işten ayrılma niyetlerinin yüksek olduğunu (Ak, 2011: 98) ancak çalışanın iş bulma olanakları kısıtlı, becerileri yetersiz ve emek arzı yaptığı iş piyasası kötü bir durumda ise, iş doyumu çok düşük olsa da mevcut işinde kalmayı tercih edebildiklerini göstermektedir (Feldman ve Arnold, 1983: 203).

Alanyazında örgütsel sessizlik davranışı üzerine farklı çalışmalarla karşılaşılmakta ancak örgütsel sessizlik ve bireylerin işten ayrılma davranışlarına vurgu yapan çok az çalışma bulunmaktadır (Elçi vd., 2014: 1301). Sessizlik davranışı odaklı çalışmalar genellikle işyeri kaynaklı değişkenler ile incelenmiştir (Elçi vd., 2014: 1300). Örgütte yüksek sadakate sahip çalışanların memnuniyetsizliklerini seslerini yükselterek ifade edebildikleri, örgütsel bağlılığı düşük işgörenlerin ise memnuniyetsizliğini örgütten ayrılarak gösterdiği görülmektedir (Afşar, 2013: 45).

Sağlık sektöründe hemşirelerin işten ayrılmaları ile ilgili çalışmalarında Hayes vd. (2006: 239-243), işten ayrılma niyetinin oluşumunu ve işten ayrılma davranışına neden olan etkenleri, iş tatmini, çevresel, kişisel ve işle ilgili değişkenler, iş yükü, stres, tükenmişlik, yönetim biçimi, güçlendirme ve özerklik, kariyer fırsatları, çalışma programları gibi örgütsel faktörler, bireysel faktörler ve ekonomik faktörler olarak belirlemişlerdir. İtalya'da hemşireler üzerinde yapılan bir araştırmada, hemşirelerin işten ayrılma davranışı, işten geri çekilme süreci veya mevcut görevli oldukları servisten ayrılma ile başlayıp mesleği bırakmaya kadar uzanan zincir reaksiyon olarak tarif edilmiştir (Cortese, 2012: 312). Sağlık çalışanları ile ilgili yayınlanan OECD raporunda yer alan ve 2006 yılında işten ayrılmayı düşünen hemşire oranları Kanada'da $\%$ 17, İngiltere'de \% 39, Almanya'da \% 17, İskoçya'da \% 30 ve ABD'de \%23 olup bu yöndeki bulgulara anlam katacak yöndedir (Simoens vd., 2005).

Hemşirelerin işgücü planlama modelleri her ne kadar tıp doktorları ile benzerlik içinde bulunsa da hemşirelerin birçoğunun normal emeklilik yaşından önce mesleklerini bırakma eğiliminde olmaları (Tourangeau ve Cranley 2006: 497) geleceğe yönelik stratejik insan kaynakları planlamasında problemler yaşanmasına neden olabilmektedir. Tıp doktorlarının standart emeklilik yaşını aşan çalışma hayatları olmasına karşın hemşireler, iş tatminsizliği, iş güvencesizliği gibi nedenlerle işten ayrılma niyeti taşımakta ancak maddi yetersizlikler nedeniyle işlerini bırakamamaktadırlar (Öztürk vd., 2005: 13).

\section{4. İş Güvencesi Memnuniyeti}

Bireylerin iş ilişkisi ile ilgili düşüncelerinin temelinde işlerinin sürekliliğini sağlamak düşüncesi bulunmaktadır (Hotamışlı ve Şenol, 2011: 24). İ̧̧gören açısından onun toplumsal konumuna katkıda bulunan iş tanımının güvence altına alınması, kanunlarla koruma içinde bulunması, işveren-işgören ilişkisinin en önemli öğesini oluşturmaktadır.

İşletmelerin kıyasıya rekabet içinde oldukları birbirleri ile yarıştıkları günümüz koşullarında işverenler nitelikli işgücünü elinde tutabilmek, işgörenler ise sürekliliğini sağladığı işlerini kaybetmemek adına yazılı olmayan doğal bir sözleşme içerisinde bulunmaktadırlar. Örgütsel yapılar ile işgörenler arasında karşılıklı çıkar ilişkisinin aktif bir şekilde hissedildiği günümüz çalışma yaşamında, işgören emeği karşılığında iyi bir ücret ve iş güvencesi talep ederken diğer tarafta yer alan işverenler ise işgörenlerin performanslarının iyi olmasını istemekte ve bu talep işgörenlerde sorumluluk hissi meydana getirmektedir. İşgörenlerin işe bağlılık hissetmesinde başlıca engel hususlar ise işten çıkarılma, iş kazaları, sağlık problemleri ve geleceğin güvence al- 
tında bulunmamasının verdiği korku olarak sıralanmaktadır (Agin, 2010). Bu nedenle iş güvencesinin hedefinde işgörenlerin işten ayrılma niyetini tetikleyen iş doyumsuzluğu ile iş güvencesizliği algısının azaltılması bulunmaktadır (Lim, 1996: 173).

Yönetim ve organizasyon alanyazınında iş güvencesi konusu son çeyrek yüzyılda üzerinde çalışılan önemli bir kavram olmasına rağmen (Önder ve Wasti, 2002: 27) iş güvencesini yalnızca yönetim biliminin konusu olarak kabul etmek yanlış bir algılaya neden olacaktır. Örneğin ülkemizde iş güvencesi kavramı hukuk alanında da önemli bir yere sahip durumda ve 4447 ve 4857 sayılı kanunlar ile düzenlenmiş şekilde iş hayatına yön vermektedir.

Probst (1998), işgörenin mevcut durumdaki işinin devamlılı̆ına ilişkin algısını iş güvencesi olarak tanımlayarak iş güvencesi ile ilişkili algı ve tutumların birbirlerinde ayrı olduğunu savunmuştur. Bu nedenle çalışanın mevcut işinin sürekliliğine ilişkin algısı ile bu algıdan dolayı oluşan memnuniyetin ayrı ayrı ölçümlenmesinin daha etkili sonuçlar vereceğini düşünerek iş güvencesi memnuniyeti ile iş güvencesi algısını iki farklı ölçek ile değerlendirmiştir (Önder ve Wasti 2002).

İs güvencesizliğinin işten ayrılma niyeti ile pozitif yönlü ve anlamlı ilişki içerinde olduğu yapılan araştırmalarda ortaya koyulmuş olup (Ashford vd., 1989; Arnold ve Feldman, 1982) Türkiye'de de son yıllarda yapılan çalışmalarda elde edilen bulgular da paralellik arz etmektedir (Hotamışlı ve Şenol, 2011; Poyraz ve Kama, 2008).

\section{Araştırmanın Yöntemi}

\subsection{Prosedür}

Araştırma açıklayıcı ve ilişkisel model çerçevesinde nicel araştırma yöntemlerinden betimsel, bağıntısal ve nedensel karşılaştırma yöntemleri kullanılarak yürütülmüştür. Örgütsel sessizlik, iş güvencesi ve işten ayrılma niyeti ilişkisini belirlemeye yönelik ölçek, gerekli izinler alınarak İstanbul'da bir özel hastaneler zincirinde çalışan 359 sağıık hizmetleri üzerinde MartNisan 2015 aylarında uygulanmıştır. Zaman ve maliyet tasarrufu, kitle ulaşılabilirliğine olan kolaylık nedeniyle (Arıkan, 2004: 128) kolayda örnekleme yöntemi ile bahse konu hastaneler grubunun iç intranet sistemi üzerinden e-posta ile gönderilmiş ve veriler toplanmıştır. Veriler SPSS 21.0 ve AMOS programında analiz edilmiştir.

\subsubsection{Araştırma Modeli}

Araştırmanın temel değişkenleri arasındaki etkileşim Şekil 1.'de verilen simgesel araştırma modelinde gösterilmiştir.

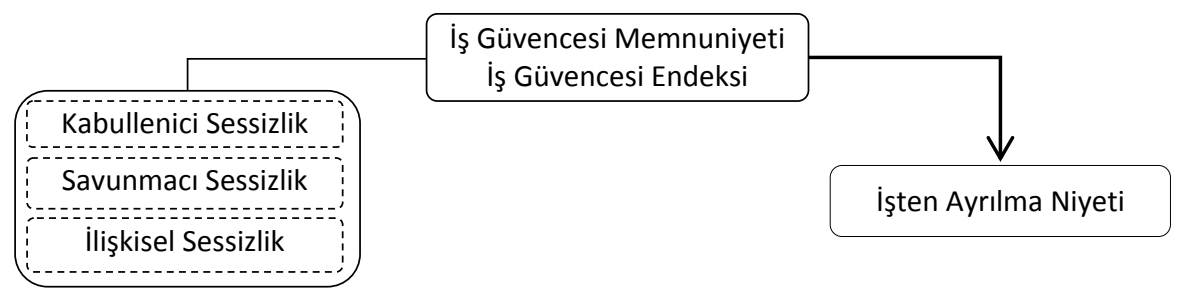

Şekil 1: Simgesel Araştırma Modeli 


\subsubsection{Araştırma Soruları}

Araştırma kapsamında aşağıdaki sorulara cevap aranmıştır:

(1) Sağlık hizmetleri çalışanlarının örgütsel sessizliğe ilişkin tutumları ile işten ayrılma niyetleri, iş güvencesi memnuniyetleri ve iş güvencesi endeksi arasındaki etkileşimler hangi düzeydedir?

(2) Sağlık hizmetleri çalışanlarının örgütsel sessizlik tutumları ile işten ayrılma niyeti etkileşiminde iş güvencesi memnuniyeti ve iş güvencesi endeksinin aracılık rolü hangi düzeydedir?

(3) Sağlık hizmetleri çalışanlarının örgütsel sessizliğe ilişkin tutumları ile işten ayrılma niyetleri ve iş güvencesi memnuniyetleri hangi demografik değişkenler bağlamında farklılaşmaktadır?

\subsubsection{Araştırmada Kullanılan Ölçekler}

Demografik Bilgi Formu: Katılımcıların cinsiyet, yaş, öğrenim durumu, mesleki statü, mesleki kıdem, medenî durum ve çalıştıkları sağıık servisi türü gibi verilerinden oluşmaktadır.

Örgütsel Sessizlik Ölçeği: Örgütsel sessizlik tutumları ölçeği, Dyne vd. (2003) tarafından geliştirilen toplam 15 ifadeden oluşmakta ve alt boyutları bağlamında; kabullenici sessizlik, savunmacı sessizlik ve ilişkisel sessizlik tutumlarını ölçümlemektedir. Taşkıran (2010) tarafından Türkçeye uyarlanan bahse konu ölçek, Aktaş ve Şimşek (2015: 213) tarafından yapılan araştırmada ise alan uzmanı bir öğretim üyesi tarafından çevirideki bazı ifadeler orijinal ölçek ile karşılaştırılarak tekrar düzenlenmiştir. Bu araştırmada cevaplar $5^{\prime}$ li Likert ölçeği kullanılarak toplanmıştır. Taşkıran (2010: 148) tarafından İstanbul'da bulunan 5 yıldızlı otel işletmelerinde yapılan araştırmada ölçeğin güvenirliği 0,891, Aktaş ve Şimşek (2015: 215) tarafından İstanbul'daki bir kamu kuruluşunda yapılan araştırmada ölçeğin güvenirliği 0,812 olarak tespit edilmiştir.

Işten Ayrılma Niyeti Ölçeği: Araştırmada, Wayne vd. (1997) tarafından geliştirilen "Işsten Ayrılma Niyeti Ölçeği" kullanılmıştır. Ölçek, üç ifadeden oluşmakta ve tek boyutludur. Küçükusta (2007: 147) tarafından konaklama işletmelerinde yapılan çalışmada ölçeğin güvenirliği 0.69 tespit edilmiştir. Bu araştırmada cevaplar 5'li Likert ölçeği kullanılarak toplanmıştır.

Iş Güvencesi Endeksi Ölçeği: Bireylerin iş güvencesine karşı duydukları memnuniyet algısının mevcut işin sürekliliğine ilişkin algısından bağımsız olması gerektiğini savunan Probst (1998), tek boyutlu iş güvencesi endeksi ölçeğini geliştirmiştir. Bu araştırmada, İ̧̧ Güvencesi Endeksi (IGE) ölçeğinin, Önder ve Wasti (2002) tarafından Türkçeye uyarlanmış hali uygulanmış olup anılan çalışmada ölçeğin güvenirliği 0.80 olarak tespit edilmiştir. Ölçek, "Evet", "Kararsızım" ve "Hayır" seçenekli altışar sorudan oluşmaktadır.

İş Güvencesi Memnuniyeti Ölçeği: Probst (1998) tarafından İş Güvencesi Endeksi (IGE) ile birlikte işgörenlerin iş güvencelerine karşı duydukları memnuniyeti ölçmek üzere tek boyuttan oluşan İş Güvencesi Memnuniyeti (IGM) ölçeğini de geliştirilmiş olup bunun nedeni ise algılanan iş güvencesinin diğer örgütsel değişkenler üzerindeki etkisinin ancak iş güvencesinden memnuniyeti ile ortaya çıkabileceğinin düşünülmesidir (Önder ve Wasti, 2002). Araştırmada bahse konu ölçeğin, Önder ve Wasti (2002) tarafından Türkçeye çevrilmiş hali uygulanmış olup anılan çalışmada ölçeğin güvenirliği 0.87 olarak tespit edilmiştir. İş Güvencesi Memnuniyeti (IGM) ölçeği "Evet", "Kararsızım" ve "Hayır" seçenekli altışar sorudan oluşmaktadır. 


\subsection{Katılımcıların Demografik Profili}

Araştırmaya veri sağlayan katılımcıların demografik profilleri incelendiğinde; $18-24$ yaş aralığında bulunanlar 145 kişi (\% 43.0), 26-30 yaş aralığında bulunanlar 71 kişi $(\% 21,1), 31-35$ yaş aralığında bulunanlar 42 kişi (\%12,5), 36-40 yaş aralığında bulunanlar 48 kişi $(\% 14,2)$ ve 41 yaş üstünde bulunanlar ise $31(\% 9,2)$ kişidir. Katılımcıların 175 (\%51,9)'i evli, 162 (\%48,1)'si bekârdır. $270(\% 80,1)^{\prime}$ ini kadınlar, $67(\% 19,9)$ 'sini ise erkekler oluşturmaktadır. Lise öğrenimine sahip $193(\% 57,3)$ kişi, ön lisans mezunu $66(\% 19,6)$ kişi ve lisans-yüksek lisans öğrenimi görmüş $78(\% 23,1)$ kişi bulunmaktadır. Meslekî çalışma süreleri incelendiğinde; 1-5 yıl arası meslekî deneyimi bulunanlar 153 (\% 45,4), 6-10 yıl arası meslekî deneyimi bulunanlar 77 (\%22,8), 11-15 yıl arası meslekî deneyimi bulunanlar 42 (\%12,5), 16-20 yıl arası meslekî deneyimi bulunanlar 39 (\%11,6), 21 yıl ve üstü meslekî kıdemi bulunanlar ise $26(\% 7,7)$ kişidir. €1000-2000 arasında ücret alan kişi sayısı 200 (\%59,3), €2001-3000 arasında ücret alan kişi sayısı 95 (\%28,2), €3000 ve üzeri ücret alan kişi sayısı ise 42 (\%12,5)'dir. 261 (\%77,4) kişinin çalışan, $76(\% 22,6)$ kişinin ise yönetici statüsündedir. Acil servis/yoğun bakım ünitelerinde çalışan işgören sayısı $124(\% 36,8)$, klinik ve diğer sağlık ünitelerinde çalışan işgören sayısı ise $213(\% 63,2)$ kişi olup meslekî statüsü hemşirelik olan çalışan sayısı $262(\% 77,7)$, ve diğer sağlık hizmetlerinde görev yapan işgören sayısı ise 75 (\%22,3)'dir.

\subsection{Veri Analizi}

Verilerin analizine geçilmeden önce 359 katılımcıdan toplanan veriler düzenlenmiş, eksik verisi olan 15 katılımc ile uç değer analizi ve tanımlayıcı istatistikler kapsamında standart z değerleri $z>3$ ve $z<-3$ aralığında (Raykov ve Marcoulides, 2012: 69) bulunmayan 7 katılımcının verisi silinerek toplamda 22 katılımcıya ait veri araştırma dışında bırakılmıştır. Diğer eksik veriler ise incelenerek seri ortalama değerleri ile değiştirilmiştir.

\subsection{Geçerlilik ve Güvenilirlik Bulguları}

Geçerlilik bir değişkenin madde kovaryanslarının altında yatan neden olup olmadığı ile ilgilenmektedir (DeVellis, 2014: 59). Yapı geçerliliğinin tespitinde açıklayıcı ve doğrulayıcı faktör analizleri için yapısal eşitlik yöntemi ile temel bileşenler yöntemi ve varimax döndürme yöntemi uygulanmıştır. Verilerin faktör analizine uygun olup olmadığı Kaiser-Meyer-Olkin (KMO) örneklem yeterliliği testi ve Bartlett Küresellik Testi ile kontrol edilmiştir. Faktör yüklerinin 0,5 değerinden yüksek olması durumunda faktörler oluşturulmuştur (Büyüköztürk, 2010: 124).

Örgütsel sessizlik ölçeğine ilişkin geçerlik ve faktör analizi kapsamında AMOS programı ile doğrulayıcı faktör analizi yapılmıştır. Mevcut model ile temel model arasındaki uyumu bulgulayan Karşılaştırmalı Uyum İndeksi (CFI)'nin 0.90 ve üzerinde bir değerde olması önerilen modelin uyumlu olduğunu göstermektedir (Tabacknick ve Fidell, 2001). Ayrıca mevcut modelin temel model ile uyumsuzluğunu bulgulamak için Kestirim Hatası Kareler Ortalaması Karekökü (RMSEA) değerinin sıfıra yakın olması ise modelin iyi kurulduğunu göstermektedir (Kline, 2011). Varsayılan modelin kullanılmasıyla iyileşen uygunluk durumunu belirleyen Normlanmış Uyum İyiliği İndeksi (NFI) de 0-1 arasında değer alan ve 1'e yaklaştıkça daha iyi olduğu değerlendirilen ölçütlerden bir diğeridir. Örgütsel sessizlik ölçeği için yapılan doğrulayıcı faktör analizinde ortaya çıkan sonuçlara göre; verilerin modele göre uyum sağladığı ( $\chi 2=258.692$, df $=86, \chi 2 / d f=3.00$ ) ve modelin çeşitli indekslere göre uyum değerlendirmesinin ise (CFI =0.958, RMSEA $=0.077, \mathrm{NFI}=0,939$ ve $\mathrm{TLI}=0.949$ ) iyi olduğu değerlendirilmektedir. Ölçeğe ait mevcut üç boyutlu yapı korunmuştur. 
Işsten ayrılma niyeti ölçeği faktör analizi için veri setine ilişkin değerler: $K M O=0,712$ ve $X^{2}$ Bartlett Test (3) =538,211 $p<0.0001$ olarak hesaplanmıştır. Toplam açıklanan varyans yüzde 79,911'dir. Ölçeğin üç sorudan oluşan tek boyutlu yapısını koruduğu tespit edilmiştir.

İş güvencesi memnuniyeti ölçeğine ilişkin yapılan geçerlik analizi sonucunda ölçeğin tek boyutu içinde bulunan "Iş̧ yerinizde iş güvenceniz nasıldır ?" sorusuna verilebilecek cevaplar arasında bulunan "Stresli" ifadesi ölçeğin güvenilirliğini önemli düzeyde düşürdüğü $(\alpha=, 336)$ için çıkartılarak analizlere dâhil edilmemiştir. Bu araştırmada faktör analizi için veri setine ilişkin değerler: $\mathrm{KMO}=0,770$ ve $\mathrm{X}^{2}$ Bartlett Test $(10)=491,304 \mathrm{p}<0.0001$ olarak hesaplanmıştır. Toplam açıklanan varyans yüzde 54.340'dır.

İş güvencesi endeksi ölçeğine ilişkin yapılan geçerlik analizi sonucunda ölçeğin tek boyutu içinde bulunan "Bu kuruluşta gelecekteki istihdam durumunuz nedir ?" sorusuna verilebilecek cevaplar arasındaki "Sabit" ifadesi, ölçeğin güvenilirliğini önemli düzeyde düşürdüğü $(\alpha=, 266)$ için çıkartılarak analizlere dâhil edilmemiştir. Bu araştırmada faktör analizi için veri setine ilişkin değerler: $\mathrm{KMO}=0,754$ ve $\mathrm{X}^{2}$ Bartlett Test $(10)=498,128 \mathrm{p}<0.0001$ olarak hesaplanmıştır. Toplam açıklanan varyans yüzde 53.940 'dır.

Örgütsel sessizlik ölçeğinin Cronbach Alpha değeri 0,884 olup işten ayrılma niyeti ölçeğinin Cronbach Alpha değeri 0,874 ve iş güvencesi memnuniyeti (IGM) ölçeğinin Cronbach Alpha değeri 0,788 ve iş güvencesi endeksi (IGE) ölçeğinin Cronbach Alpha değeri ise 0,785 olarak hesaplanmıştır.

\subsection{Araştırma Bulguları}

\subsubsection{Korelasyon Analizleri}

Korelasyon analizinde iki değişkenin birbirleri arasındaki ilişkinin yönü ve şiddeti belirlenmektedir. Korelasyon katsayıların değerlendirilmesi için $r<0,40$ oranı zayıf, $r=0,40$ ile0,59 oranları orta, $r=0,60$ ile0,74 oranları iyi ve $r>0,75$ 'den yüksek oranlar ise mükemmel olarak kabul edilmektedir (Şencan 2005: 279). Pearson Korelasyon Analizi sonucunda elde edilen bilgiler Tablo 1'de sunulmuştur.

\section{Tablo 1: Pearson Korelasyon Değerleri}

\begin{tabular}{|c|c|c|c|c|c|c|c|c|c|}
\hline Değişkenler & Ort. & SS & 1 & 2 & 3 & 4 & 5 & 6 & 7 \\
\hline 1. İşten Ayrılma Niyeti & 2,87 & 1,06 & 1 &,$- 413^{* *}$ &,$- 456^{* *}$ & $287^{* *}$ &, $333^{* *}$ &,$- 137^{*}$ & $258^{* *}$ \\
\hline 2. İş Güvencesi Endeksi & 5,69 & 4,00 & & 1 & $697^{* *}$ &,$- 253^{* *}$ &,$- 306^{* *}$ & 065 &,$- 255^{* *}$ \\
\hline 3. İş Güvencesi Memnuniyeti & 6,60 & 4,16 & & & 1 &,$- 230^{* *}$ &,$- 321^{* *}$ & $146^{* *}$ &,$- 223^{* *}$ \\
\hline 4. Kabullenici Sessizlik & 2,60 & 85 & & & & 1 &, $769^{* *}$ & ,025 &, $876^{* *}$ \\
\hline 5. Savunmacı Sessizlik & 2,31 & ,98 & & & & & 1 &,- 021 &, $875^{* *}$ \\
\hline 6. İlişkisel Sessizlik & 3,94 & 68 & & & & & & 1 & $366^{* *}$ \\
\hline 7. Örgütsel Sessizlik & 2,95 & 62 & & & & & & & 1 \\
\hline
\end{tabular}

*Korelasyon0.05 seviyesinde anlamlı (2-yönlü) ${ }^{* *}$ Korelasyon0.01 seviyesinde anlamlı (2-yönlü)

Tablo 1'deki veriler incelendiğinde; işten ayrılma niyetinin; iş güvencesi endeksi ( $r=-, 413)$, iş güvencesi memnuniyeti $(r=-, 456)$ ve ilişkisel sessizlik $(r=-, 137)$ ile ters yönlü korelasyon içinde olduğu, kabullenici sessizlik $(r=, 287)$, savunmacı sessizlik $(r=, 333)$ ve bütünsel olarak sessizlik $(r=, 258)$ ile aynı yönlü korelasyon göstermektedir. İ̧̧ güvencesi endeksinin ise; kabullenici sessizlik $(r=-, 253)$, savunmacı sessizlik $(r=-, 306)$ ve bütünsel olarak sessizlik $(r=-$ ,255) ile ters yönlü korelasyon içinde bulunmaktadır. İş güvencesi memnuniyetinin de; kabullenici sessizlik $(r=-, 230)$, savunmacı sessizlik $(r=-, 321)$ ve bütünsel olarak sessizlik $(r=-, 223)$ ile ters yönlü korelasyon içinde olduğu ancak ilişkisel sessizlik $(r=, 146)$ aynı yönlü korelasyon içinde olduğu tespit edilmiştir. 
Korelasyon analizinden yola çıkarak geleceğe ilişkin iş güvencesi algıları ile mevcut işlerinden duydukları memnuniyetleri azaldığında işgörenin işten ayrılma niyetlerinin artacağı, kabullenici ve savunmacı sessizliklerinin arttığında ise işten ayrılma niyetlerinin artış göstererek, iş güvencesi memnuniyetleri ile işlerinin devamlılığına ilişkin algılarının düşeceği değerlendirmesinde bulunabilmektedir.

Ayrıca, örgüt ile çevrede bulunanları korumaya yönelik ilişkisel sessizlik tutumunun kabullenici sessizlik ve savunmacı sessizliğe göre işten ayrılma niyeti ve iş güvencesi memnuniyeti ile zıt bir yol izlediği, işten ayrılma niyetinin artması durumunda ilişkisel sessizliğin azalacağı buna karşın ise iş güvencesi memnuniyetindeki artışın ilişkisel sessizliği de artıracağı değerlendirilmektedir. Ancak iş güvencesinin geleceğine ilişkin algıyı oluşturan iş güvencesi endeksi ile ilişkisel sessizlik arasında anlamlı bir ilişki tespit edilememiştir. İş güvencesi endeksi (IGE) ile iş güvencesi memnuniyetinin (IGM) birbirleri ile yüksek korelasyon içinde olması, Probst (1998)'un çalışması $(r=, 730)$ ve Önder ve Wasti (2002)'nin çalışması ile de $(r=, 540)$ uyumludur.

\subsubsection{Regresyon Analizleri}

Regresyon analizi, aralarında ilişki olan iki veya daha fazla değişkenden birinin bağımlı değişken, diğerlerinin ise bağımsız değişkenler olarak ayrılması ile aralarındaki ilişki boyutunun matematiksel eşitlik ile açıklanmasıdır (Büyüköztürk, 2010). Regresyon analizleri öncesinde değişkenler arasında çoklu doğrusal bağıntı problemi test edilerek VIF değerlerinin 10'dan küçük olduğu ve çoklu bağlantı olmadığı doğrulanmıştır. Verilerde otokorelasyon durumu için Durbin-Watson değerleri 1,5-2,5 arasında dağıldığı görülerek otokorelasyon olmadığı görülmüştür. Eşvaryanslılık durumunun incelenmesi sonucunda ise regresyon hata terimlerine ait varyansın sabit olduğu ve hata terimlerinin normale yakın dağıldığı tespit edilmiştir (Orhunbilge, 2010; Orhunbilge 2002).

\subsubsection{Regresyon Analizleri}

Araştırmanın birinci sorusunu cevaplamak amacıyla bütünsel olarak örgütsel sessizlik, iş güvencesi memnuniyeti ve iş güvencesi endeksinin işten ayrılma niyeti üzerindeki etki düzeyini belirlemek için yapılan çoklu regresyon analizinde adım adım seçme metodu uygulanmıştır (Tablo 2).

Tablo 2: Örgütsel Sessizlik, Işs Güvencesi Memnuniyeti ve İsten Ayrılma Niyeti Etkileşimine ilişkin Regresyon Analizi

\begin{tabular}{lccc}
\hline Bağımlı Değişken: Iş̧ten Ayrılma Niyeti & & & \\
\hline \hline Bağımsız Değişken: & $b$ & $t$ & $p$ \\
İş Güvencesi Memnuniyeti & $-0,314$ & $-4,728$ & 0,000 \\
Örgütsel Sessizlik & 0,148 & 3,008 & 0,003 \\
İ̧̧ Güvencesi Endeksi & $-0,156$ & $-2,336$ & 0,020 \\
\hline $\mathrm{R}=0,496 \quad$ Düzeltilmiş $\mathrm{R}^{2}=0,239$ & & $\mathrm{~F}=36,268$ & $\mathrm{p}=0,000$ \\
\hline
\end{tabular}

Elde edilen bulgulara göre; iş güvencesi memnuniyetinin $(\beta=-0,314, p=0,000)$, örgütsel sessizliğin $(\beta=0,148, p=0,003)$ ve iş güvencesi endeksinin $(\beta=-0,156, p=0,020)$ işten ayrılma niyeti üzerinde anlamlı etkilerinin bulunduğu belirlenmiş $(F=36,268 ; p=0,000)$ ve modelin açıklama gücünün $\left(R^{2}=0,239\right)$ olduğu ortaya koyulmuştur. Örgütsel sessizliğin alt boyutlarını da kapsayacak şekilde iş güvencesi memnuniyeti ve iş güvencesi endeksinin, işten ayrılma niyeti üzerindeki etkilerini belirlemek maksadıyla da yapılan regresyon analizi Tablo 3'de sunulmuştur. 
Tablo 3: Örgütsel Sessizlik Alt Boyutları, iş Güvencesi Memnuniyeti ve İsten Ayrılma Niyeti Etkileşimine Iliş̧in Regresyon Analizi

\begin{tabular}{lccc}
\hline Bağımlı Değişken: Işsten Ayrılma Niyeti & \multicolumn{3}{c}{} \\
\hline Bağımsız Değişken: & $b$ & $t$ & $p$ \\
İş Güvencesi Memnuniyeti & $-0,287$ & $-4,305$ & 0,000 \\
Savunmacı Sessizlik & 0,193 & 3,848 & 0,000 \\
Iş̧ Güvencesi Endeksi & $-0,154$ & $-2,329$ & 0,020 \\
\hline $\mathrm{R}=0,509 \quad$ Düzeltilmiş $\mathrm{R}^{2}=0,252$ & & $\mathrm{~F}=38,750$ & $\mathrm{p}=0,000$ \\
\hline
\end{tabular}

Regresyon analizine göre işten ayrılma niyeti üzerinde iş güvencesi memnuniyetinin ( $\beta=-$ $0,287, p=0,000$, savunmacı sessizliğin $(\beta=0,193, p=0,000)$ ve iş güvencesi endeksinin $(\beta=-0,154$, $p=0,020)$ anlamlı etkilerinin olduğu görülmüş, $(F=38,750 ; p=0,000)$ ve modelin açıklama gücünün ise $\left(R^{2}=0,252\right)$ olduğu belirlenmiştir.

\subsubsection{Aracılık Etkisinin Tespit Edilmesine Yönelik Regresyon Analizleri}

Araştırmanın ikinci sorusuna ilişkin örgütsel sessizlik ve işten ayrılma niyeti etkileşiminde iş güvencesi memnuniyetinin ve iş güvencesi endeksinin aracılık rolü incelenmiştir. Değişkenler arasında aracılık ilişkisinin varlığından söz edebilmek için; a. Bağımsız değişkendeki değişimin aracı değişkene etkisinde istatistiksel olarak anlamlı bir sonuca ulaşılmalı, b. Aracı değişkendeki değişimin bağımlı değişkene etkisinde istatistiksel olarak anlamlı bir sonuç elde edilmeli ve c. Aracı değişkenin ve bağımsız değişkenin birlikte analiz edilmesi sonucunda bağımsız değişkenin bağımlı değişken üzerinde etkisinde istatistiksel olarak anlamlı bir şekilde azalma ya da tamamen ortadan kalkma gözlemlenmelidir (Baron ve Kenny, 1986: 1173-1176). Bu etkinin tamamen ortadan kalkması durumunda ise güçlü ve tek bir aracı değişken olarak tam aracılık etkisi ortaya çıkmakta, bağımsız değişken ile bağımlı değişken arasındaki ilişkide düşüş olması durumunda başka aracı değişkenlerin de varlığının söz konusu olabileceği değerlendirilerek, kısmî aracılık etkisi meydana gelmektedir.

\subsubsection{1. İ̧̧ Güvencesi Memnuniyetinin Aracılık Rolü}

Örgütsel sessizlik tutumu ile işten ayrılma niyeti etkileşiminde iş güvencesi memnuniyetinin aracı etkisini araştırmak üzere yapılan üç aşamalı regresyon analizi sonucu Tablo 4'de olduğu gibidir. Yapılan regresyon analizinin birinci aşamasında bağımlı değişken olarak işten ayrılma niyeti, bağımsız değişken olarak ise örgütsel sessizlik alınmıştır. Birinci modelde ( $b=0.274, p=0.000$ ) olup istatistiksel olarak anlamlıdır. İkinci aşamada bağımlı değişken olarak iş güvencesi memnuniyeti (aracı değişken) ile yine örgütsel sessizlik bağımsız değişken olarak ele alınmış olup $(\beta=-0.233, p=0.000)$ istatistiksel olarak anlamlıdır. Üçüncü aşamada ise işten ayrılma niyeti bağımlı değişken ve iş güvencesi memnuniyeti ile örgütsel sessizlik bağımsız değişkenler olarak modellemeye dâhil edilmiştir. İş güvencesi memnuniyetinin etki katsayısı $(b=-0.415, p=0.000)$, örgütsel sessizliğin etki katsayısı $(b=0.177, p=0.000)$ olarak tespit edilmiştir $(F=52,102, p<0.001)$. Bu bulgulara göre örgütsel sessizlik ile işten ayrılma niyeti etkileşiminde iş güvencesi memnuniyetinin kısmî aracılık etkisinden söz edilebilir. 
Tablo 4: Örgütsel Sessizlik ile Işten Ayrılma Niyeti Etkileşiminde iş̧ Güvencesi $\quad$ Memnuniyetinin Aracı Rolü: Regresyon Analizi

\begin{tabular}{|c|c|c|c|}
\hline \multicolumn{4}{|c|}{ Birinci Aşama Regresyon Analizi Sonuçları } \\
\hline \multicolumn{4}{|l|}{ Bağımlı Değişken: Işsten Ayrılma Niyeti } \\
\hline Bağımsız Değişken: & B & $t$ & $p$ \\
\hline Örgütsel Sessizlik & 0,274 & 5,207 & 0,000 \\
\hline Düzeltilmiş $R^{2}=0,075$ & \multicolumn{2}{|c|}{$F=27,113$} & $p=0,000$ \\
\hline \multicolumn{4}{|c|}{ Ikinci Aşama Regresyon Analizi Sonuçları } \\
\hline \multicolumn{4}{|c|}{ Bağımlı Değişken: Iş Güvencesi Memnuniyeti (Aracı Değişken) } \\
\hline Bağımsız Değişken: & B & $t$ & $p$ \\
\hline Örgütsel Sessizlik & $-0,233$ & $-4,378$ & 0,000 \\
\hline Düzeltilmiş $R^{2}=0,051$ & & & $p=0,000$ \\
\hline \multicolumn{4}{|c|}{ Üçüncü Aşama Regresyon Analizi Sonuçları } \\
\hline \multicolumn{4}{|l|}{ Bağımlı Değişken: Işsten Ayrılma Niyeti } \\
\hline Bağımsız Değişken: & B & $t$ & $p$ \\
\hline İş Güvencesi Memnuniyeti & $-0,415$ & $-8,450$ & 0,000 \\
\hline Örgütsel Sessizlik & 0,177 & 3,605 & 0,000 \\
\hline Düzeltilmiş $R^{2}=0,233$ & & & $p=0,000$ \\
\hline
\end{tabular}

\subsubsection{2. İ̧̧ Güvencesi Endeksinin Aracılık Rolü}

Örgütsel sessizlik ile işten ayrılma niyeti etkileşiminde iş güvencesi endeksinin aracı rolüne ilişkin yapılan regresyon analizi Tablo 5'de verilmiştir. Regresyon analizinin birinci aşaması yukarıda Tablo 4'de verilen analizin (bağımlı değişken: işten ayrılma niyeti, bağımsız değişken: örgütsel sessizlik) aynısıdır. İkinci aşamada aracı değişken iş güvencesi endeksi ile yine örgütsel sessizlik bağımsız değişken olarak ele alınmış olup $(\beta=-0.257, p=0.000)$ istatistiksel olarak anlamlıdır. Üçüncü aşamada ise işten ayrılma niyeti bağımlı değişken ve iş güvencesi endeksi ile örgütsel sessizlik bağımsız değişkenler olarak modele dâhil edilmiştir. İş güvencesi endeksinin etki katsayısı $(b=-0.367, p=0.000)$, örgütsel sessizliğin etki katsayısı $(b=0.179, p=0.000)$ olarak hesaplanmıştır. Üçüncü modeldeki $F$ değeri 41,926 ile $p<0.001$ 'de anlamlı seviyededir. Bu bulgulardan yola çıkarak örgütsel sessizlik ile işten ayrılma niyeti etkileşiminde iş güvencesi endeksinin kısmî aracılık etkisinden söz edilebilir.

Tablo 5: Örgütsel sessizlik ile işten ayrılma niyeti etkileşiminde iş güvencesi endeksinin aracı rolü: Regresyon Analizi

\begin{tabular}{|c|c|c|c|}
\hline \multicolumn{4}{|c|}{ İkinci Aşama Regresyon Analizi Sonuçları } \\
\hline \multicolumn{4}{|c|}{ Bağımlı Değişken: Iş Güvencesi Endeksi (Aracı Değişken) } \\
\hline Bağımsız Değişken: & 8 & $t$ & $p$ \\
\hline Örgütsel Sessizlik & $-0,257$ & $-4,875$ & 0,000 \\
\hline Düzeltilmiş $R^{2}=0,063$ & \multicolumn{2}{|c|}{$F=23,763$} & $p=0,000$ \\
\hline \multicolumn{4}{|c|}{ Üçüncü Aşama Regresyon Analizi Sonuçları } \\
\hline \multicolumn{4}{|l|}{ Bağımlı Değişken: İşten Ayrılma Niyeti } \\
\hline Bağımsız Değişken: & 8 & $t$ & $p$ \\
\hline İş Güvencesi Endeksi & $-0,367$ & $-7,250$ & 0,000 \\
\hline Örgütsel Sessizlik & 0,179 & 3,539 & 0,000 \\
\hline Düzeltilmiş $R^{2}=0,196$ & \multicolumn{2}{|c|}{$F=41,926$} & $p=0,000$ \\
\hline
\end{tabular}




\subsubsection{Demografik Değişkenler Bağlamında Varyans Analizleri}

Araştırmanın son sorusu bağlamında işgörenlerin, örgütsel sessizlik ve alt boyutları ile iş güvencesi endeksi, iş güvencesi memnuniyeti ve işten ayrılma niyeti için verdikleri cevapların demografik özelliklerine göre farklılıkları analiz edilmiştir. Cinsiyet, yaş, medenî durum ve çalışan/yönetici statüsü değişkenleri için t testi, diğer demografik değişkenler için ise tek yön ANOVA testi uygulanmıştır. ANOVA analizinde homojenlik taşıyan gruplar arasındaki ortalamalar arasındaki farklılı̆ın hangi demografik gruplar arasında olduğunun tespit edilebilmesi maksadıyla çoklu karşılaştırma testleri (Scheffe, LSD) uygulanmıştır. Varyans analizlerine ilişkin elde edilen sonuçlar Tablo 6'da sunulmuştur.

Tablo 6: Varyans Analizleri

\begin{tabular}{|c|c|c|}
\hline Cinsiyet & Kadın & Erkek \\
\hline Bütünsel Sessizlik $[t(335)=-2.425, p=0,017]$ & $\overline{\mathrm{X}}=2.90, \mathrm{SS}=.58$ & $\overline{\mathrm{X}}=3.13, \mathrm{SS}=.71$ \\
\hline Savunmacı Sessizlik [t(335)=-3.028, p=0,003] & $\overline{\mathrm{X}}=2.23, \mathrm{SS}=.95$ & $\overline{\mathrm{X}}=2.63, \mathrm{SS}=1.05$ \\
\hline Kabullenici Sessizlik [t(335)=-1.485, p=0,139] & \multirow{4}{*}{\multicolumn{2}{|c|}{$\begin{array}{l}\text { Ortalamalar arasında istatiksel olarak anlamlı } \\
\text { fark bulunmamaktadır. }\end{array}$}} \\
\hline İlişkisel Sessizlik [t(335)=-1.202, p=0,230] & & \\
\hline İşten Ayrılma Niyeti $[t(335)=-1,540, p=0,125]$ & & \\
\hline İş Güvencesi Endeksi [t(335)=0.692, p=0,489] & & \\
\hline Medenî Durum & Bekâr & Evli \\
\hline Bütünsel Sessizlik $[t(335)=2.548, p=0,011]$ & $\overline{\mathrm{X}}=3.03, \mathrm{SS}=.66$ & $\overline{\mathrm{X}}=2.86, \mathrm{SS}=.56$ \\
\hline Kabullenici Sessizlik [t(335)=2.794, $p=0,006]$ & $\overline{\mathrm{X}}=2.72, \mathrm{SS}=.89)$ & $\overline{\mathrm{X}}=2.46, \mathrm{SS}=.79$ \\
\hline Savunmacı Sessizlik [t(335)=2.922, p=0,004] & $\overline{\mathrm{X}}=2.46, \mathrm{SS}=1.02)$ & $\overline{\mathrm{X}}=2.15, \mathrm{SS}=.91$ \\
\hline İşten Ayrılma Niyeti $[t(335)=2.312, p=0,021]$ & $\overline{\mathrm{X}}=3.00, \mathrm{SS}=1.12)$ & $\overline{\mathrm{X}}=2.74, \mathrm{SS}=.97$ \\
\hline İlişkisel Sessizlik [t(335)=-.774, p=0,440] & \multirow{3}{*}{\multicolumn{2}{|c|}{$\begin{array}{l}\text { Ortalamalar arasında istatiksel olarak anlamlı } \\
\text { fark bulunmamaktadır. }\end{array}$}} \\
\hline İş Güvencesi Memnuniyeti $[\mathrm{t}(335)=-1.600, \mathrm{p}=0,110]$ & & \\
\hline İş Güvencesi Endeksi [t(335)=1.969, p=0,050] & & \\
\hline Statü & Çalışan & Yönetici \\
\hline Bütünsel Sessizlik $[t(335)=5.010, p=0,000]$ & $\overline{\mathrm{X}}=3.02, \mathrm{SS}=.64$ & $\overline{\mathrm{X}}=2.70, \mathrm{SS}=.44$ \\
\hline Kabullenici Sessizlik [t(335)=4.576, p=0,000] & $\overline{\mathrm{X}}=2.69, \mathrm{SS}=.88$ & $\overline{\mathrm{X}}=2.27, \mathrm{SS}=.65$ \\
\hline Savunmacı Sessizlik $[\mathrm{t}(335)=4.598, \mathrm{p}=0,000]$ & $\overline{\mathrm{X}}=2.44, \mathrm{SS}=1.00$ & $\overline{\mathrm{X}}=1.84, \mathrm{SS}=.75$ \\
\hline Savunmacı Sessizlik $[t(335)=4.598, p=0,000]$ & $\overline{\mathrm{X}}=2.44, \mathrm{SS}=1.00$ & $\overline{\mathrm{X}}=1.84, \mathrm{SS}=.75$ \\
\hline İş Güvencesi Memnuniyeti $[t(335)=-3.602, p=0,000]$ & $\overline{\mathrm{X}}=6.17, \mathrm{SS}=4.04$ & $\overline{\mathrm{X}}=8.09, \mathrm{SS}=4.24$ \\
\hline İş Güvencesi Endeksi [t(335)=-2,507, p=0,014] & $\overline{\mathrm{X}}=5.36, \mathrm{SS}=3.77$ & $\overline{\mathrm{X}}=6.80, \mathrm{SS}=4.55$ \\
\hline İşten Ayrılma Niyeti [t(335)=3,287, p=0,001] & $\overline{\mathrm{X}}=2.98, \mathrm{SS}=1.08$ & $\overline{\mathrm{X}}=2.53, \mathrm{SS}=.92$ \\
\hline İlişkisel Sessizlik [t(335)=-.576, $p=0,565]$ & $\begin{array}{r}\text { Ortalamalar arasınd } \\
\text { fark bulu } \\
\end{array}$ & $\begin{array}{l}\text { ksel olarak anlamlı } \\
\text { aktadır. }\end{array}$ \\
\hline
\end{tabular}




\begin{tabular}{|c|c|c|c|}
\hline Yaş & $26-30$ & $31-35$ & $36-40$ \\
\hline Kabullenici Sessizlik ( $F=2.046 ; p=0.088$ ) & \multirow{4}{*}{\multicolumn{3}{|c|}{$\begin{array}{l}\text { Ortalamalar arasında istatiksel olarak anlamlı fark bulunma- } \\
\text { maktadır. }\end{array}$}} \\
\hline İlişkisel Sessizlik ( $F=1.330 ; p=0.258$ ) & & & \\
\hline İş Güvencesi Endeksi ( $F=1.731 ; p=0.143)$ & & & \\
\hline $\begin{array}{l}\text { Bütünsel Örgütsel Sessizlik } \\
(F=1,021 ; p=0.397)\end{array}$ & & & \\
\hline \multirow{2}{*}{ İşten Ayrılma Niyeti $(F=2.715 ; p=0.030)$} & $18-25$ & $26-30$ & $41+$ \\
\hline & $\overline{\mathrm{X}}=3.04, \mathrm{SS}=1.07$ & $\overline{\mathrm{X}}=2.93, \mathrm{SS}=1.08$ & $\overline{\mathrm{X}}=2.69, \mathrm{SS}=1.03$ \\
\hline \multirow{2}{*}{$\begin{array}{l}\text { İş Güvencesi Memnuniyeti } \\
(\mathrm{F}=2.813 ; \mathrm{p}=0.025)\end{array}$} & $18-25$ & $36-40$ & $41+$ \\
\hline & $\overline{\mathrm{X}}=6.06, \mathrm{SS}=3.87$ & $\overline{\mathrm{X}}=7.68, \mathrm{SS}=4.21$ & $\overline{\mathrm{X}}=8.25, \mathrm{SS}=4.47$ \\
\hline \multirow[b]{2}{*}{ Savunmacı Sessizlik ( $F=2.702 ; p=0.031)$} & \multicolumn{2}{|l|}{$18-25$} & $41+$ \\
\hline & \multicolumn{2}{|l|}{$\overline{\mathrm{X}}=2.45, \mathrm{SS}=1.00$} & $\overline{\mathrm{X}}=1.84, \mathrm{SS}=.77$ \\
\hline Öğrenim Durumları & $18-25$ & $31-35$ & $36-40$ \\
\hline \multicolumn{4}{|l|}{$\begin{array}{l}\text { Bütünsel Örgütsel Sessizlik } \\
(\mathrm{F}=1.237 ; \mathrm{p}=0.292)\end{array}$} \\
\hline \multicolumn{4}{|l|}{ Kabullenici Sessizlik ( $F=1.993 ; p=0.138$ ) } \\
\hline Savunmacı Sessizlik (F=1.636; $p=0.196)$ & \multirow{3}{*}{\multicolumn{3}{|c|}{$\begin{array}{l}\text { Ortalamalar arasında istatiksel olarak anlamlı fark bulunma- } \\
\text { maktadır. }\end{array}$}} \\
\hline İlişkisel Sessizlik ( $F=0.557 ; p=0.574)$, & & & \\
\hline İşten Ayrılma Niyeti(F=1.237; $p=0.292)$, & & & \\
\hline \multicolumn{4}{|l|}{ İş Güvencesi Endeksi ( $F=2.345 ; p=0.097)$} \\
\hline \multicolumn{4}{|l|}{$\begin{array}{l}\text { İş Güvencesi Memnuniyeti } \\
(\mathrm{F}=1.468 ; \mathrm{p}=0.232)\end{array}$} \\
\hline Meslekî Kıdem & $1-5$ & $11-15$ & $16-20$ \\
\hline İlişkisel Sessizlik ( $F=2.071 ; p=0.084)$ & \multirow{2}{*}{\multicolumn{3}{|c|}{$\begin{array}{l}\text { Ortalamalar arasında istatiksel olarak anlamlı fark bulunma- } \\
\text { maktadır. }\end{array}$}} \\
\hline \multirow[t]{2}{*}{ İ̧̧ Güvencesi Endeksi $(\mathrm{F}=2.404 ; \mathrm{p}=0.050)$} & & & \\
\hline & $1-5$ & $16-20$ & $21+$ \\
\hline Savunmacı Sessizlik (F=6.228; $p=0.000)$ & $\overline{\mathrm{X}}=2.55, \mathrm{SS}=1.06$ & $\overline{\mathrm{X}}=2.01, \mathrm{SS}=.93)$ & $\overline{\mathrm{X}}=1.76, \mathrm{SS}=.56$ \\
\hline Kabullenici Sessizlik ( $F=3.464 ; p=0.009)$ & $\overline{\mathrm{X}}=2.74, \mathrm{SS}=.94$ & $\overline{\mathrm{X}}=2.28, \mathrm{SS}=.68)$ & $\overline{\mathrm{X}}=2.36, \mathrm{SS}=.59$ \\
\hline $\begin{array}{l}\text { İş Güvencesi Memnuniyeti } \\
(\mathrm{F}=3.414 ; \mathrm{p}=0.009)\end{array}$ & $\overline{\mathrm{X}}=5.99, \mathrm{SS}=3.93$ & $\overline{\mathrm{X}}=8.05, \mathrm{SS}=4.04)$ & $\overline{\mathrm{X}}=8.46, \mathrm{SS}=4.50$ \\
\hline \multirow{2}{*}{$\begin{array}{l}\text { Bütünsel Örgütsel Sessizlik } \\
(F=3.021 ; p=0.018)\end{array}$} & \multicolumn{2}{|l|}{$1-5$} & $21+$ \\
\hline & \multicolumn{2}{|l|}{$\overline{\mathrm{X}}=3.06, \mathrm{SS}=.70$} & $\overline{\mathrm{X}}=2.77, \mathrm{SS}=.34$ \\
\hline \multirow{2}{*}{ İşten Ayrılma Niyeti ( $F=4.112 ; p=0.003)$} & \multicolumn{2}{|l|}{$1-5$} & $16-20$ \\
\hline & \multicolumn{2}{|l|}{$\overline{\mathrm{X}}=3.09, \mathrm{SS}=1.11$} & $\overline{\mathrm{X}}=2.41, \mathrm{SS}=1.00$ \\
\hline Ücret & $€ 1000-2000$ & $€ 2001-3000$ & $€ 3000+$ \\
\hline İlişkisel Sessizlik ( $F=2.622 ; p=0.074)$ & \multicolumn{3}{|c|}{$\begin{array}{l}\text { Ortalamalar arasında istatiksel olarak anlamlı fark bulunma- } \\
\text { maktadır. }\end{array}$} \\
\hline Kabullenici Sessizlik ( $F=10.114 ; p=0.000)$ & $\overline{\mathrm{X}}=2.75, \mathrm{SS}=.87$ & $\overline{\mathrm{X}}=2.46, \mathrm{SS}=.77$ & $\overline{\mathrm{X}}=2.17, \mathrm{SS}=.71$ \\
\hline Savunmacı Sessizlik $(F=14.186 ; p=0.000)$ & $\overline{\mathrm{X}}=2.52, \mathrm{SS}=1.01$ & $\overline{\mathrm{X}}=2.12, \mathrm{SS}=.89$ & $\overline{\mathrm{X}}=1.74, \mathrm{SS}=.73$ \\
\hline \multirow[t]{2}{*}{ Bütünsel Sessizlik ( $F=8.252 ; p=0.000)$} & $\overline{\mathrm{X}}=3.05, \mathrm{SS}=.66$ & $\overline{\mathrm{X}}=2.84, \mathrm{SS}=.56$ & $\overline{\mathrm{X}}=2.69, \mathrm{SS}=.40$ \\
\hline & \multicolumn{2}{|l|}{$€ 1000-2000$} & $€ 3000+$ \\
\hline $\begin{array}{l}\text { İş Güvencesi Memnuniyeti } \\
(\mathrm{F}=15.986 ; \mathrm{p}=0.000)\end{array}$ & $\overline{\mathrm{X}}=5.99, \mathrm{SS}=3.99$ & & $\overline{\mathrm{X}}=9.80, \mathrm{SS}=3.78$ \\
\hline İş Güvencesi Endeksi (F=16.807; p=0.000) & $\overline{\mathrm{X}}=5.10, \mathrm{SS}=3.57$ & & $\overline{\mathrm{X}}=8.85, \mathrm{SS}=4.69$ \\
\hline İşten Ayrılma Niyeti $(F=15.696 ; p=0.000)$ & $\overline{\mathrm{X}}=3.05, \mathrm{SS}=1.06$ & & $\overline{\mathrm{X}}=2.08, \mathrm{SS}=0.65$ \\
\hline
\end{tabular}




\section{Sonuç}

Elde edilen bulgulara göre işgörenlerin örgütsel sessizliğe ilişkin tutumları ile işten ayrılma niyeti arasında anlamlı bir ilişkinin olduğu, alanyazında bulunan örgütsel sessizlik ile işten ayrılma niyeti arasındaki ilişkiyi destekler niteliktedir (Bagheri vd., 2012; Hoffmann 2006; Meyer ve Allen, 1991; Kolarska ve Aldrich, 1980).

İşörenlerin, örgütsel sessizliğin alt boyutu savunmacı sessizlik tutumları ile işten ayrılma niyetleri arasında anlamlandırılabilecek bir ilişki tespit edilmiştir. Savunmacı sessizliğin korkuya dayalı ve bireyin kendini risk altında hissetmesine (Dyne vd., 2003: 1363) neden olabilecek etkenler içermesi nedeniyle, Gouldner (1960)'ın Karşlıklılık Norm Teorisi ile uyumlu olarak birey tarafından olumlu bir durum olarak nitelendirilmeyen savunmacı sessizlik davranışının, onun işten ayrılma niyetini de olumsuz etkileyeceği değerlendirilmektedir.

Örgüt içerisinde iş güvencesi memnuniyeti yüksek olan işgörenlerin geleceğe güvenle bakabildiği ve örgütsel bağııı̆̆ının artarak ve işten ayrılma niyetini taşımadığı değerlendirilmektedir. Kendisini iş akdi konusunda güvence altında hissetmeyen bireyler ise bilgi ve yeteneklerini örgütte iş rollerinin gerektirdiği en alt düzeyde kullanmayı tercih edebilmektedir.

İş güvencesinden duyulan memnuniyet ile iş güvencesi algısının, işten ayrılma niyeti üzerindeki etkilerine bakıldığında ters yönlü bir ilişki tespit edilmiştir. İş güvencesi memnuniyetindeki azalma işten ayrılma niyetinde artışa neden olabilmektedir.

Çalışanların, Ajzen (1991)'in Planlanmış Davranış Teorisi çerçevesinde sergileyeceği tutuma ilişkin kararlarında, bireyin iş güvencesinden kaynaklı algısında olumlu bir durum oluştuğunda Hobfoll (1989)'un Kaynakların Korunması Teorisinde belirttiği gibi değer yüklediği iş güvencesini kaybetmemek adına işten ayrılma niyetinden vazgeçmesi mümkün olabilmektedir.

Araştırmada elde edilen diğer bir önemli bir sonuç ise iş güvencesinin algısı ile memnuniyetinin ayrı kavramlar olmasına rağmen, bütünsel bir anlam çıkarımı sağlama konusunda daha doyurucu veri elde etmek için sağladığı katkının birlikte değerlendirebilirliğinin test edilmesidir. Mevcut işin sürekliliğine olan algı ile birçok örgütsel değişkenden etkilenebilen hâlihazırda devam eden iş güvencesine karşı duyulan memnuniyetin, ayrı ayrı analizlere dâhil edilmesi, örgütsel sessizlik ile işten ayrılma niyetinin etkileşiminde aracılığın tespit edilmesinde daha kapsamlı sonuçlar sağlamıştır. Bu anlamda, alanyazında benzer çalışmaların çok az olması nedeniyle örgütsel sessizlik ile işten ayrılma niyeti etkileşiminde iş güvencesi memnuniyeti ve iş güvencesi algısı kavramlarının ilk defa ele alındığı değerlendirilmektedir.

Araştırmaya konu olan değişkenlerin Tablo 6 'da belirtildiği üzere demografik faktörlerden etkilendiği tespit edilmiştir. Bu araştırmada sessizlik tutumları ile yaş grupları arasında istatiksel olarak anlamlı fark tespit edilememiştir. Bu tespit Özdemir ve Uğur (2013: 276)'nın Sivas'ta kamu ve özel sektör işletmelerinde yaptığı araştırma ile Atasever (2013: 106-107) tarafından tekstil sektöründe yapılan çalışmanın yaş bulgusu ile uyumludur.

Bu çalışmada işten ayrıma niyeti ile yaş değişkeni arasında anlamlı farkın bulunmaması Agin (2010: 66-68)'in çalışmasındaki bulgular ile paralellik göstermektedir. Araştırmaya katılanların öğrenim durumları ile sessizlik tutumları, işten ayrılma niyetleri ve iş güvencesi memnuniyetleri arasında istatiksel olarak anlamlı bir ilişki tespit edilmemiştir. Borkowski ve diğ. (2007: 164-166) ise araştırmalarında, hemşirelerde eğitim durumu yükseldikçe işten ayrılma niyetinin düştüğünü tespit etmişlerdir.

Araştırmada meslekî kıdem ile kabullenici ve savunmacı sessizlik tutumları arasında anlamIı ilişki olduğu ancak ilişkisel sessizlik tutumu ile meslekî kıdem arasında anlamlı bir farkın ol- 
madığı bulunmuştur. Bu durum Tayfun ve Çatır (2013: 126)'ın sağlık sektöründe yaptığı araştırmasında bulguladığı meslek kıdemi fazla olan hemşirelerin örgütü korumaya yönelik sessizlik davranışı sergilediği yönündeki bulguları ile farklı bir sonuç arz etmektedir.

İlişkisel sessizlik tutumlarında çalışan ve yöneticiler arasındaki ortalamalarda fark bulunmaması ve katılımcıların genel anlamda ilişkisel sessizlik ortalamalarının bütünsel sessizlik tutumlarının ortalamalarından yüksek olması örgüte ait geliştirici, düzeltici fikirlerin işgörenler tarafından söylenmesi ve örgüte ait bilgilerin korunması açısından çalışanların ve yöneticilerin aynı doğrultuda hareket ettikleri değerlendirilmektedir.

Araştırmada öğrenim durumları ortalamaları ile örgütsel sessizlik, işten ayrılma niyeti ve iş güvencesi memnuniyeti arasında anlamlı farklılıklar tespit edilememiştir. İşten ayrılma niyetinin 41 yaş ve üstü çalışanlarda daha düşük olması, hâlihazırda yürürlükte olan Sosyal Güvenlik Kanununda belirtilen çalışma yılını doldurmuş ancak yaş nedeniyle emekliye ayrılamayan bireylerin sosyal güvencesiz kalmamak için sistem dışına çıkamamasının getirdiği bir yansıma olarak değerlendirilebilir.

Insan, doğası gereği doğumundan itibaren iletişime geçen bir varlıktır. Bireyin iş yaşamında da devam eden bu iletişimin örgütsel anlamda uyum içinde devam edebilmesi için işgörenin sessizliğinin azaltılmasında yönetimsel müdahalelerin ve desteğin büyük rolü bulunmaktadır. Sessizliğin istenmeyen etkisi durumundaki işten ayrılmaların, iş gücü devir oranlarını artırmasının ve dolaylı olarak maliyet getiren bu unsurun ortadan kaldırılması için aracı değişkenlerin doğru tespit edilmesi gereklidir.

Bu araştırmada, çalışanların yöneticilerine oranla kabullenici sessizlik ve savunmacı sessizlik tutumlarının daha yüksek olduğu belirlenmiştir. Bu bulgu Özdemir ve Uğur (2013: 272)'un araştırmasındaki bulguyu destekler niteliktedir. Bu durum yöneticilerin "astların sesi" olması açısından değerlendirildiğinde sessizliğin sesine kulak verilmesi ve sesliliğin desteklenmesi, örgüt içi iletişimi özellikle de yönetim ile olan ilişkiyi güçlendirecektir. Ayrıca işgörenlerin konuşmasının, -en azından- susmasından daha yararlı olduğu göz önünde tutularak örgütün iş süreçlerine katkıda bulunması sağlanmalıdır.

Hem iş güvencesi memnuniyetinin hem de iş güvencesi endeksinin, işten ayrılma niyeti ile aralarındaki etkileşimin yüksekliği göz önünde bulundurulduğunda, stratejik insan kaynakları uygulamalarında Evrenselci kuram çerçevesinde en iyi uygulamalar arasında yer alan iş güvencesinin (Gürbüz, 2013: 10) çalışan için bir ön koşul özelliği taşıdığı söylenebilir. Bu nedenle iş güvencesi kavramının her çalışana iş sözleşmesi çerçevesinde temel seviyede verilmesinin yanında iyileştirilmiş ve sürdürebilir iş güvencesinin örgüt-birey iletişiminde her fırsatta ifade edilerek bir tür psikolojik sözleşme maddesi haline getirilmesinin olumlu etkileri olacağı değerlendirilmektedir.

\subsection{Gelecek Araştırmalar için Öneriler}

a. Sosyal bilimlerde yapılan araştırmaların tüm evreni kapsama olanağının bulunmaması ve bu nedenle genellemelerin yapılabilme olasılığının imkânsızığı bu araştırma için de geçerlidir. Araştırmanın bulguları; araştırmanın evreni, örneklem sayısı ve özellikleriyle sınırlı kalmıştır. Farklı evrenler, örneklemler ve diğer iş kolları ile yapılacak nitel ve nicel benzer araştırmalar, örgütsel davranış alanyazınına katkı sağlayarak karşılaştırılabilir veriler elde etme imkânı sağlayacaktır. 
b. Örgütsel sessizlik ile ilgili yapılan araştırmaların alanyazında çok fazla bulunmaması, varolan çalışmaların da farklı iş kollarına ait olması nedeniyle bu konudaki araştırmaların artırımasının fayda sağlayacağı değerlendirilmektedir.

c. Bu araştırma tam zamanlı çalışan işgörenler üzerinde yapılmıştır. Farklı sonuçlar alınabileceği değerlendirilen yarı zamanlı ya da esnek çalışma saatlerine sahip işgörenler üzerinde de uygulanmasının alanyazına katkı sağlayacağı değerlendirilmektedir. 


\section{Kaynaklar}

AFŞAR, L. (2013). “Örgütsel Sessizlik ve Örgütsel Güven İlişkisi: Konuya İlişkin Bir Araştırma”, Yüksek Lisans Tezi. İstanbul: İstanbul Üniversitesi SBE.

AGiN, Ö. (2010). “işse Bağlanma Düzeyinin İşten Ayrılma Niyeti Üzerine Etkileri” Yüksek Lisans Tezi. Kocaeli: Kocaeli Üniversitesi SBE.

AJZEN, I. (1991). "The Theory of Planned Behavior", Organizational Behavior And Human Decision Processes, 50(2), 179-211.

AK, Ö. (2011). “Personel Seçim Sürecinde Aday Başvuru Yolları ile İş Doyumu ve İşten Ayrılma Niyeti Arasındaki İlişki Üzerine Bir Araştırma”, Yüksek Lisans Tezi. İstanbul: Marmara Üniversitesi SBE.

AKTAŞ, H. ve ŞiMŞEK, E. (2014). “Örgütsel Sessizlik ile Algılanan Bireysel Performans, Örgüt Kültürü ve Demografik Değişkenler Arasındaki Etkileşim”, Akdeniz Üniversitesi i.i.̇.F. Dergisi, 14(28), 24-52.

AKTAŞ, H. ve ŞiMŞEK, E. (2015). “Bireylerin Örgütsel Sessizlik Tutumlarında İş Doyumu ve Duygusal Tükenmişlik Algılarının Rolü”, Uluslararası Yönetim İktisat ve İşletme Dergisi, 11(24), 205-230.

ARIKAN, R. (2004). Araştırma Teknikleri ve Rapor Hazırlama. 4. Baskı, Ankara: Asil Yayın Dağıtım.

ARNOLD, H.J. ve FELDMAN, D.C. (1982). "A Multivariate Analysis of the Determinants of Job Turnover", Journal of Applied Psychology, 67(3), 350-360.

ASHFORD, S.J., LEE, C. \& BOBKO, P. (1989). “Content, Cause, and Consequences of job Insecurity: A Theory-Based Measure and Substantive Test", Academy of Management Journal, 32(4), 803-829.

ATASEVER, M. (2013). "Yıldırmanın Örgütsel Sessizlik Üzerine Bir Etkisi ve İşletmelerde Bir Araştırma”, Yüksek Lisans Tezi. Denizli: Pamukkale Üniversitesi SBE.

AVERY, D.R.ve QUINONES, M.A. (2004). “Individual Differences and The Voice Effect The Moderating Role of Value of Voice", Group \& Organization Management, 29(1), 106-124.

BAGHERI, G., ZAREI, R. \& AEEN, M.N. (2012). “Organizational Silence (Basic Concepts and its Development Factors)”, Ideal Type of Management, 1(1), 47-58.

BARON, R. M., \& KENNY, D. A. (1986). “The Moderator-Mediator Variable Distinction in Social Psychological Research: Conceptual, Strategic, and Statistical Considerations", Journal of Personality and Social Psychology. 51(6), 11731182.

BECKER, B.E., ve GERHART, B. (1996). "The Impact of Human Resource Management on Organizational Performance: Progress and Prospects", Academy of Management Journal, 39(4), 779-801.

BEHESHTIFAR, M., BORHANI, H. \& MOGHADAM, M.N. (2012). "Destructive Role of Employee Silence in Organizational Success", International Journal of Academic Research in Business \& Social Sciences, 2(11), 275-282.

BORKOWSKI, N., AMANN, R., SONG, S.H. \& WEISS, C. (2007). “Nurses' Intent to Leave The Profession: Issues Related to Gender, Ethnicity, and Educational Level", Health Care Management Review. 32(2), pp. 160-167.

BOWEN, F. \& BLACKMON, K. (2003). "Spirals of Silence: The Dynamic Effects of Diversity on Organizational Voice", Journal of Management Studies, 40(6), 1393-1417.

BRINSFIELD, C.T. (2009). “Employee Silence: Investigation of Dimensionality, Development of Measures, and Examination of Related Factors", Doktora Tezi. Ohio: Philosophy in the Graduate School of The Ohio State University.

BÜYÜKÖZTÜRK, Ş. (2010). Sosyal Bilimler İçin Veri Analizi El Kitabı: İstatistik, Araştırma Deseni, SPSS Uygulamaları ve Yorum. Ankara: Pegem Akademi Yayıncılık.

BÜYÜKYILMAZ, O. ve ÇAKMAK, A. F. (2014). “ilişkisel ve İşlemsel Psikolojik Sözleşmede Algılanan İhlalin İşten Ayrılma Niyeti ve Algılanan Örgütsel Destek Üzerindeki Etkisi”, Ege Akademik Bakış, 14(4), 583-596.

CHO, S., JOHANSON, M. M., \& GUCHAiT, P. (2009). "Employees Intent to Leave: A Comparison of Determinants of Intent to Leave Versus Intent to Stay", International Journal of Hospitality Management, 28(3), 374-381.

CORTESE, C.G. (2012). "Predictors of Critical Care Nurses' Intention to Leave The Unit, The Hospital, And The Nursing Profession", Open Journal of Nursing, 2, 311-326.

ÇAKICI, A. (2007). "Örgütlerde Sessizlik: Sessizliğin Teorik Temelleri ve Dinamikleri”, Çukurova Üniversitesi Sosyal Bilimler Enstitüsü Dergisi, 16(1), 145-162.

ÇAKıCl, A. (2010). Örgütlerde İşgören Sessizliği. Ankara: Detay Yayıncılık.

ÇEKMECELIOĞLU, H. G. (2014). “Göreve ve İnsana Yönelik Liderlik Tarzlarının Örgütsel Bağlııı, İş Performansı ve İşten Ayrılma Niyeti Üzerindeki Etkileri”, Kocaeli Üniversitesi Sosyal Bilimler Dergisi, 28, 21-34. 
DELERY, J.E. \& Doty. D.H. (1996). “Modes of Theorizing in Strategic Human Resource Management: Test Of Universalistic, Contingency, And Configurational Performance Predictions", The Academy of Management Journal, 39(4), 802-35.

DENiZ, N., Noyan, A. ve Ertosun, Ö. G. (2013). “The Relationship Between Employee Silence and Organizational Commitment in a Private Healthcare Company", Procedia-Social and Behavioral Sciences, 99, 691-700.

DEVELLIS, R.F., (2012). Scale Development. 3.Edition. U.K.: Sage Publications. Totan T. (Çev.), Ankara: Nobel Yayıncılık.

DYNE, L.V., Ang, S. ve Botero, I.C. (2003). “Conceptualizing Employee Silence and Employee Voice as Multidimensional Constructs", Journal of Management Studies, 40(6), 1359-1392.

EGAN, T.M., Yang, B. \& Bartlett, K. R. (2004). "The Effects of Organizational Learning Culture and Job Satisfaction on Motivation to Transfer Learning and Turnover Intention", Human Resource Development Quarterly. 15(3), 279301.

ELÇi, M., Melisa, E.K., Alpkan, L. \& Şener, i. (2014). "The Mediating Role of Mobbing on the Relationship Between Organizational Silence and Turnover Intention", Procedia-Social and Behavioral Sciences, 150, 1298-1309.

FELDMAN, D. C. \& Arnold, H. J. (1983). Managing Individual and Group Behavior in Organizations. New York: McGrawHill College.

GOULDNER, A.W. (1960). "The Norm of Reciprocity: A Preliminary Statement", American Sociological Review, 25, 161-178.

GÜRBÜZ, S. (2013). "Stratejik İnsan Kaynakları Yönetiminin Kuramsal Temelleri: Evrenselci, Koşul Bağımlılık ve Yapısalcı Yaklaşımlar", Gazi Üniversitesi İktisadi Ve İdari Bilimler Fakültesi Dergisi, 15(1), 63-97.

HAYES, L.J., O’Brien-Pallas, L., Duffield, C., Shamian, J., Buchan, J., Hughes, F., Stone, P. W. (2006). “Nurse Turnover: A Literature Review", International Journal of Nursing Studies. 43(2), 237-263.

HENRIKSEN, K. \& Dayton, E. (2006). "Organizational Silence and Hidden Threats to Patient Safety", Health Services Research. 41:4(2), 1539-1554.

HIRSCHMAN, A. O. (1970). Exit, Voice, and Loyalty: Responses to Decline in Firms, Organizations, and States. London, England: Harvard University Press.

HOBFOLL, S.E. (1989). "Conservation of Resources a New Attempt at Conceptualizing Stress", American Psychologist, 44(3), 513-524.

HOFFMANN, E.A. (2006). "Exit and Voice: Organizational Loyalty and Dispute Resolution Strategies", Social Forces, 84(4), 2313-2330.

HOTAMIŞLI, M. ve Şenol, F. (2011). İş Güvencesinin Motivasyon Açısından Önemi. Ankara: Nobel Akademik Yayıncılık.

HUSELID, M.A. (1995). “The Impact Of Human Resource Management Practices On Turnover, Productivity, And Corporate Financial Performance", Academy Of Management Journal, 38(3), 635-67.

işçi, E. (2010). “Psikolojik Sözleşme İhlalinin Örgütsel Vatandaşlık Davranışı ve İşten Ayrılma Niyeti Üzerindeki Etkisinde Güvenin Rolü”, Doktora Tezi. İstanbul: Marmara Üniversitesi SBE.

KARACAOĞLU, K. ve Cingöz, A. (2009). “işsgören Sessizliğinin Kaynağı Olarak Liderlik Davranışı ve Örgütsel Adalet Algısı”, 17. Ulusal Yönetim ve Organizasyon Kongresi, 21-23 Mayıs 2009, Eskişehir: Eskişehir Osmangazi Üniversitesi, 700-707.

KEELEY, M. \& Graham, J.W. (1991). “Exit, Voice and Ethics”, Journal of Business Ethics, 10(5), 349-355.

KLINE, R.B. (2011). Principles and Practices of Structural Equating Modeling. New York, NY: The Guilford Press.

KOLARSKA, L. \& Aldrich, H. (1980). “Exit, Voice, and Silence: Consumers' and Managers' Responses to Organizational Decline", Organization Studies, 1(1), 41-58.

KÜÇÜKUSTA, D. (2007). "Konaklama İşletmelerinde İş-Yaşam Dengesinin Çalışma Yaşamı Kalitesi Üzerindeki Etkisi”, Doktora Tezi. İzmir: Dokuz Eylül Üniversitesi SBE.

LIM, V.K. (1996). “Job Insecurity and its Outcomes: Moderating Effects of Work-Based and Nonwork-Based Social Support", Human Relations, 49(2), 171-194.

LUCHAK, A.A. (2003). "What Kind of Voice do Loyal Employees Use?”, British Journal of Industrial Relations, 41(1), 115-134.

MEYER, J.P. ve Allen, N.J. (1991). "A Three-Component Conceptualization of Organizational Commitment", Human Resource Management Review. 1(1),61-89. 
MEYER, J.P. STANLEY, D.J., HERSCOVITCH, L. \& TOPOLNYTSKY, L. (2002). “Affective, Continuance, and Normative Commitment to the Organization: A Meta-Analysis of Antecedents, Correlates, and Consequences", Journal of Vocational Behavior. 61(1), 20-52.

MILLIKEN, F.J. MORRISON, E.W. \& HEWLIN, P.F. (2003). “An Exploratory Study of Employee Silence: Issues That Employees Don't Communicate Upward and Why", Journal of Management Studies, 40(6), 1453-1476.

MORRISON, E. W. \& MiLLiKEN, F.J. (2000). “Organizational Silence: A Barrier to Change and Development in A Pluralistic World", Academy of Management Review, 25(4), 706-725.

ORHUNBiLGE, N. (2002). Uygulamalı Regresyon ve Korelasyon Analizi. İstanbul: İstanbul Üniversitesi, İşletme Fakültesi Yayını.

ORHUNBiLGE, N. (2010). Çok Değişkenli İstatistik Yöntemler. İstanbul: İstanbul Üniversitesi, İşletme Fakültesi Yayını.

OSTERMAN, P. (1994). “How Common is Workplace Transformation and Who Adopts it?”, Industrial and Labor Relations Review, 47(2), 173-188.

ÖNDER, Ç. ve WASTi, A.S. (2002). “iş̧ Güvencesi Endeksi ve İ̧̧ Güvencesi Memnuniyeti Ölçeği: Güvenirlik ve Geçerlik Analizi", Yönetim Araştırmaları Dergisi, 2(1), 23-47.

ÖZDEMiR, L. ve UĞUR, S.S. (2013). “Çalışanların Örgütsel Ses ve Sessizlik Algılamalarının Demografik Nitelikler Açısından Değerlendirilmesi: Kamu ve Özel Sektörde Bir Araştırma”, Atatürk Üniversitesi İktisadi ve İdari Bilimler Dergisi, 27(1), 257-281.

ÖZTÜRK, M., ALPARSLAN, N., ÖZTUNÇ, G. ve AKBAŞ, M. (2005). “Adana Illinde Çeşitli Hastanelerdeki 15 Yıl ve Üstü Çalışma Süresi olan Hemşirelerin Emekliliklerine İlişkin Görüşlerinin Belirlenmesi", Journal of Anatolia Nursing and Health Sciences. 8(3), 10-18.

PERLOW, L. \& WilLiAMS, S. (2003). “Is Silence Killing Your Company?”, Harvard Business Review. 81, 52-58.

PINDER, C.C. \& HARLOS, K.P. (2001). “Employee Silence: Quiescence and Acquiescence as Responses to Perceived Injustice", Research in Personnel and Human Resources Management. 20, 331-369.

PFEFFER, J. (1994) Competitive Advantage through People: Vnctos Big the Power of the Work Force. Boston, MA: Harvard Business School Press.

PREMEAUX, S.F. \& BEDEIAN, A.G. (2003). "Breaking the Silence: The Moderating Effects of Self-Monitoring in Predicting Speaking up in the Workplace", Journal of Management Studies, 40(6), 1537-1562.

PROBST, T. M. (1998). “Antecedents and Consequences of Job Insecurity: An Integrated Model”, Doktora Tezi. Urbana, USA: University of Illinois Urbana-Champaign.

POYRAZ, K. ve KAMA, B. (2008). “Algılanan İş Güvencesinin, İş Tatmini, Örgütsel Bağlılık ve İşten Ayrılma Niyeti Üzerindeki Etkilerinin İncelenmesi”, Süleyman Demirel Üniversitesi İktisadi ve İdari Bilimler Fakültesi Dergisi, 13(2), 143-164.

RAYKOV, T. \& MARCOULIDES, G. A. (2012). An Introduction to Applied Multivariate Analysis: Routledge.

RUSBULT, C.E., FARRELL, D., ROGERS, G. \& MAiNOUS, A.G. (1988). "Impact of Exchange Variables on Exit, Voice, Loyalty, and Neglect: An Integrative Model of Responses to Declining Job Satisfaction", Academy of Management Journal, 31(3), 599-627.

SCOTT, R.L. (1993). “Dialectical Tensions of Speaking and Silence” Quarterly Journal of Speech, 79, 1-18.

SIMOENS, S., VilLeNEUVE, M. \& HURST, J. (2005). “OECD Health Working Papers, No. 19, Tackling Nurse Shortages in OECD Countries", Paris, France: Head of Publications Service OECD.

SVERKE, M., HELLGREN, J. \& NÄSWALL, K. (2002). No Security: “A Meta-Analysis and Review of Job Insecurity and its Consequences", Journal of Occupational Health Psychology, 7(3), 242-264.

ŞENCAN, H. (2005). Sosyal ve Davranışsal Ölçümlerde Güvenilirlik ve Geçerlilik. İstanbul: Seçkin Yayıncılık.

ŞiMŞEK, E. ve AKTAŞ, H. (2014). “Örgütsel Sessizlik ile Kişilik ve Yaşam Doyumu Etkileşimi: Kamu Sektöründe Bir Araştırma”, Anadolu Üniversitesi Sosyal Bilimler Dergisi, 121-136.

ŞiMŞEK, E. ve AKTAŞ, H. (2015). Illetişim Becerileri Bağlamında Yalnızlık ve Yaşam Doyumu iliş̧isi. S. Doğan (Ed.), Yaşam Doyumu Seçme Konular, 147-178. Ankara: Nobel Akademik Yayıncılık.

TABACKNICK, B. \& FIDELL L. (2001). Using Multivariate Statistics. 4th ed. Boston, MA: Allyn \& Bacon.

TANGIRALA, S. \& RAMANUJAM, R. (2008). “Employee Silence on Critical Work Issues: The Cross Level Effects of Procedural Justice Climate", Personnel Psychology. 61(1), 37-68. 
TAŞKIRAN, E. (2010). “Liderlik Tarzının Örgütsel Sessizlik Üzerindeki Etkisinde Örgütsel Adaletin Rolü ve Bir Araştırma", Doktora Tezi. İstanbul: Marmara Üniversitesi SBE.

TAYFUN, A. ve ÇATIR, O. (2013). “Örgütsel Sessizlik ve Çalışanların Performansları Arasındaki ilişki Üzerine Bir Araştırma”, İşletme Araştırmaları Dergisi, 5(3), ss. 114-134.

TETT, R P. \& MEYER, J.P. (1993). “Job Satisfaction, Organizational Commitment, Turnover Intention, and Turnover: Path Analyses Based on Meta-Analytic Findings", Personnel Psychology. 46(2), 259-293.

TOURANGEAU, A.E., \& Cranley, L.A. (2006). “Nurse Intention to Remain Employed: Understanding and Strengthening Determinants", Journal of Advanced Nursing. 55(4), 497-509.

USLU, S. ve AKTAŞ, H. (2015). “Örgütsel Sessizlik ile Örgütsel Adalet ve Yönetici Desteği Etkileşimi: Hemşireler Üzerinde Bir Araştırma”, 3.Örgütsel Davranış Kongresi Bildiriler Kitabı, 6-7 Kasım 2015, Tokat: Gaziosmanpaşa Üniversitesi, 77-83.

WALDMAN, J.D., KELLY, F., Aurora, S. \& Smith, H.L. (2004). "The Shocking Cost of Turnover in Health Care. Health Care Management Review", 29(1), 2-7.

WAYNE, S.J., SHORE, L.M., ve LIDEN, R.C. (1997). “Perceived Organizational Support and Leader-Member Exchange: A Social Exchange Perspective", Academy of Management Journal, 40(1), 82-111.

ZEHIR, C. ve ERDOGAN, E. (2011). "The Association Between Organizational Silence and Ethical Leadership Through Employee Performance", Procedia-Social and Behavioral Sciences, 24, 1389-1404.

iş KANUNU (22 Mayıs 2003). Resmi Gazete, 4857/25134.

işsizLiK SigORTASI KANUNU (08 Eylül 1999). Resmi Gazete, 4447/23810. 